\title{
Fuelwood Consumption and Participation in Community Forestry in India
}

\author{
Sushenjit Bandyopadhyay and Priya Shyamsundar \\ Environment Department, World Bank
}

\begin{abstract}
Decentralized forest management is an important policy issue in India and elsewhere. Yet, there are few careful studies of the impacts of community forestry. We try to fill this gap by analyzing National Sample Survey data from 524 villages in five states in India. Our analysis seeks to answer two key questions: a) Who participates in community forestry and what are the determinants of participation? and b) What is the impact of participation on household fuelwood consumption? We find that proximity to forests, leadership, and fuelwood dependence are significant factors in explaining village participation in community forestry. Household participation is strongly correlated with scarcity, a result that has implications for a recent policy to expand community forestry from degraded to less degraded forests. Our most important findings are that fuelwood consumption and participation are linked, and household participation has a significant positive impact on consumption. However, the presence of a village level forestry institution itself does not have a direct effect.
\end{abstract}

World Bank Policy Research Working Paper 3331, June 2004

The Policy Research Working Paper Series disseminates the findings of work in progress to encourage the exchange of ideas about development issues. An objective of the series is to get the findings out quickly, even if the presentations are less than fully polished. The papers carry the names of the authors and should be cited accordingly. The findings, interpretations, and conclusions expressed in this paper are entirely those of the authors. They do not necessarily represent the view of the World Bank, its Executive Directors, or the countries they represent. Policy Research Working Papers are available online at http://econ.worldbank.org.

\section{Acknowledgements}

We are grateful to the Trust Fund for Environmentally and Socially Sustainable Development for generous financial support. Our thanks also go to Kirk Hamilton, Team Leader, Policy and Economics Team for his support. We thank E. Somanathan, Urvashi Narain, Shreekant Gupta, Peter Jipp, Nalin Kishor, Rama Reddy, Limin Wang, and other colleagues who gave us detailed comments, and Dina Umali-Deininger for making the NSSO data available to us. 


\section{Introduction}

Only a few years ago, community management of forests was viewed as an experimental strategy. Today, it is a part of government and donor orthodoxy in forestry investment. In many parts of the world, communities living on forest fringes or within forests have regained some control over the management of these resources. For instance, in Nepal, community forest management was instituted in 1993 and is now viewed as a policy that has helped stem forest degradation (Edmonds 2002, Bardhan and others 2002). Klooster (2000) has examples of co-management of forests in Mexico leading to increased profits to local communities; and, Wily (2002) estimates that at least 4,500 rural communities in Africa are involved in some form of forest management. Thus, decentralized forestry is a worldwide phenomenon. The rights of local forestry communities have been strengthened either through management-sharing arrangements with the state, increased legal access to forests, or decentralization within government agencies.

Decentralized forestry has benefited from donor support, numerous studies documenting the ability of communities to efficiently manage common-pool resources, and a shared consensus among development practitioners about the benefits of decentralization. Yet, it is not clear that we understand the impacts community-oriented forestry. Does participating in decentralized forest management result in extraction of more or less forest products? Are there any differences in forest income between participating and nonparticipating households? Does this form of forest management improve the welfare of poor households? Does community forestry result in conservation of resources? These are some of the questions that require answers. In this paper, we seek to partially answer these questions by analyzing data on community based forest management in rural India.

While there are numerous case studies that evaluate community forestry, very few are based on large datasets and present quantitative results that are generalizable to more than a few communities. Edmonds (2002) studies the impact of community forestry on resource extraction in Nepal; this is one of the few efforts to quantitatively assess whether this government program had an impact of fuelwood extraction. Edmonds shows that there is an approximately $14 \%$ reduction in fuelwood extraction that can be attributed to the creation of forest user groups in the short-term. He builds on a tradition of quantitative program evaluation that is well established in the development literature but is relatively unknown in environmental studies. We use similar evaluation techniques to assess the impact of community forestry in India on fuelwood consumption.

Our study focuses on community forestry in India. We are interested in a government program known as Joint Forest Management (JFM) as well as traditional village level forestry institutions. JFM was launched in the early 1990s and made it possible for the forestry department to involve people and communities in the management of certain forests. JFM caught on very quickly, and by 2001 some 45,000 JFM groups were protecting approximately 12 million hectares of government forests (Kumar, 2002). ${ }^{1}$ However, several authors and practitioners contend that JFM falls short of its goals, and

\footnotetext{
${ }^{1}$ The total land area coming under community management is likely to be much higher as the above figures do not include the many traditional groups which are not recognized under JFM.
} 
that in many cases it has had a negative effect on fuelwood use by the poor (Khare and others 2000, Sundar 2000, Sarin and others, 1988). We pursue this line of reasoning and ask whether participation in JFM or other forms of traditional community forestry programs has resulted in a change in forest resource consumption.

We ask two main questions: a) Who participates in community forestry and what are the determinants of participation? and b) What is the impact of participation on household fuelwood consumption? Fuelwood consumption is treated as an indicator of resource use as well as household welfare. To answer these questions, we use a database of 524 villages and 8,307 households in five states in India. This data are obtained from the fifty-fourth round of the National Sample Survey of India. Our data do not allow us to distinguish between state-initiated (JFM) and other traditional (self-initiated or historic) forms of community forestry $(\mathrm{CF}){ }^{2}$ We include both types of forestry projects in our definition of community forestry.

The first part of our analysis focuses on villages that are engaged in community forestry. Here we try to understand what determines village choice to participate in CF activities. The goal is also to examine if there are some institutional biases toward socially and economically better-off villages. Our results do not support the existence of any clear biases. Proximity to forests, the presence of an educated person in the village (which we treat as a proxy for leadership) and fuelwood dependence are significant factors in explaining village participation in community forestry. Social and economic heterogeneity do not appear to influence collective action.

At the household level, we assess who participates in community forestry and whether this has an effect on fuelwood consumption. There are two distinct and opposite ways in which community forestry can affect fuelwood consumption. If community forestry results in net restrictions on forest use, we expect to see a decline in fuelwood consumption. ${ }^{3}$ However, if community forestry results in forest regeneration and if forest closure is carefully planned, then medium and long-term program effects will not be negative. ${ }^{4}$ Even in the short term, households that participate in community forestry may have better access to forest resources. This will happen where community and state agreements result in plantation work, forest clearing, lopping, and other forest management activities that make fuelwood or fodder available (Khare and others 2000). This is the ideal way in which CF should work - we seek to assess whether it works in this fashion in reality.

To summarize our main household level results, we find that household participation in $\mathrm{CF}$ is influenced by state geographic and policy differences, literacy, fuelwood scarcity, caste and occupational groups, and peer group effects. A key policy relevant result is that scarcity is correlated with participation. This suggests that new government guidelines to

\footnotetext{
2 Orissa and Uttar Pradesh in particular include both varieties of community organizations.

${ }^{3}$ Forest conservation is a key goal of traditional and state-initiated community forestry and has resulted in restrictions on fuelwood use in many JFM cases (Khare and others 2000).

${ }^{4}$ When coppicing species such as teak are planted as part of forest management, fuelwood benefits accrue even in the short-run.
} 
expand JFM from more to less degraded areas (where fuelwood is likely to be less scarce), need to be cautiously implemented. The rapid growth in JFM witnessed in the 1990s may not be replicable.

Our findings regarding fuelwood consumption reinforce the poverty-environment hypothesis, which suggests that fuelwood collection will decrease with wealth because of increased opportunity costs of labor and changes in preferences (Bardhan and others 2002). In our data, consumption is closely tied to collection, and decreases with increases in assets. Fuelwood consumption is also sensitive to scarcity indicators such as price and availability of village commons.

Our most important conclusion is that participation in community forestry significantly influences household fuelwood use. We find that participating households consume 744 kgs of fuelwood more than non-participant households. In rural India, fuelwood consumption can be considered an indicator of welfare, -- thus, our results show that selfreported participants benefit considerably from community forestry.

CF programs are meant to influence the entire village. Membership is intended to be universal and everybody is expected to benefit somewhat from the program. However, our analysis suggests that the presence of a CF program in the village does not have a significant effect. This implies that while community forestry markedly benefits certain households in terms of fuelwood consumption, it does not benefit all households in the village. 5

Our analysis shows that participants gain significantly from CF programs. Community forestry in India appears to be a case where some participants actively join a village forest institution and are rewarded for their membership. There is no obvious economic discrimination related to who does or does not join. Households who do not join, i.e., those who do not claim to be participants -- either because it is not important to them, or because of ignorance, or for some other reason -- do not gain in the short to medium term. We conclude that programs designed to increase participation in community forestry are important.

\section{Community Forestry and Joint Forest Management in India}

India's national forest policy of 1988 was a landmark policy for local people's rights over forest resources. The policy recognized people's participation in using and protecting forests and suggested the forest communities should develop and conserve forests together with the state forest departments. This reform in forest policy has begun to transform how forests are protected and used in India. Communities that were historically perceived to be encroachers and illegal users of forests by the state were invited to partner with the state in protecting forests. Following national implementation guidelines in 1990, various state

\footnotetext{
${ }^{5}$ Note that our definition of benefits is limited to fuelwood consumption and does not reflect other benefits of community forestry such as timber benefits, NTFP related gains, or, enhanced eco-system services.
} 
governments began implementing their own Joint Forest Management strategies. By 2001, some twenty-two states had adopted JFM (Agarwal 2001).

Under the terms of JFM, Village Forest Institutions (VFI) ${ }^{6}$ are given conditional access to specified forest products in accordance with the guidelines laid by the forest department. The products usually include fuelwood, fodder, and non-timber forest products. Forest departments also provide VFI's with information, training, and wage employment related to forest management. Initial community funds may also be provided. In many states, JFM resolutions mandate that villagers be solicited to make micro-plans for forests (Sundar 2000). Organizing into a VFI can result in access to wage employment and fuelwood through forest management activities such as lopping, clearing of debris, and cutting.

In return, VFIs agree to certain conditions such as collective protection of the forest against encroachment, poaching or timber smuggling, and, monitoring of restrictions on some types of use. After a period of protection ( 5 to 10 years or more), the VFI and its members are entitled to 25 to 100 percent of the net income from the sale of major forest produce, timber (Khare and others 2002). Commercially valuable non-timber forest products have in the past been nationalized and unavailable, but this is changing.

The organization structure and membership rules of VFIs differ in each state. For example, in Andhra Pradesh, all households living in a JFM village are eligible for JFM membership. While membership is optional for the general population of the village, it is automatic for ST and SC households (GOAP 1996). In Madhya Pradesh and Orissa, two persons (one of which must be a woman) from each household living in the JFM village are automatically considered members (GOO 1993 and GOMP 1996). In Uttar Pradesh, membership to JFM is either automatic to the village residents who are registered in the electoral rolls of the village or those who are existing members of the forest panchayat system (GOUP 1997). In West Bengal, only "economically backward people living in the vicinity of forests" are considered to be members. However, every family living in the vicinity of the forests has the option of becoming a member (GOWB 1990). In general, VFIs have an executive committee that makes major decisions. VFIs have no independent legal existence as they are usually registered with the forest department alone. ${ }^{7}$ Authority to enforce protection varies.

In addition to state supported joint forest management, India has a history of community forest management undertaken either by self-initiated groups, with NGO support, or initiated in colonial times with British support (Ghate 2003, Khare and others 2000, Ballabh and others 2002, Agarwal 2001, Lise 2000). These 'traditional' groups are particularly evident in the states of Orissa, Bihar, Uttar Pradesh and Jharkhand. For example, in Orissa, only 1,200 out of the approximately 5,000 community forest management groups are estimated to participate in JFM. (Singh 2002). It appears that

\footnotetext{
${ }^{6}$ The Village forest Institutions are known by various names in the different states. For example in Andhra Pradesh, they are known as Vana Sanrakshana Samithi (VSS) and as Forest Protection Committees (FPC) in Orissa.

${ }^{7}$ The exception is Gujarat, where committees are registered under the co-operative society act (Sundar 2000).
} 
these traditional groups are often not officially recognized under JFM rules, and in many cases are compelled to change their structure and functioning in order to be officially recognized and receive benefits associated with JFM (Sundar 2000, Khare and others 2002). ${ }^{8}$

Many papers have been written on the effectiveness of JFM and other community based efforts to manage forests. While these provide excellent insights in community efforts, they tend to be case studies and cannot be generalized. For example, Kumar (2002) bases his work on five villages in Ranchi district, and concludes that the JFM regime reflects the preferences of the rural non-poor. Lise (2000) focuses on factors influencing participation in three types of community forestry in ten villages in Haryana, Uttar Pradesh and Bihar. He concludes that participation in community forestry is associated with forest dependence, low average family education, high respondent education and greater involvement of women. Heltberg (2001) determines the impact of local institutions on JFM, using data from a protected area in Rajasthan. He suggests that in order for JFM institutions to be more effective, they need to build on existing local institutions and involve non-government organizations. Chopra and Dasgupta $(2002,2003)$ also conclude that JFM type initiatives should be based on pre-existing institutions and should be complemented with appropriate land use policies. Alsop and others (2002) study three World Bank aided projects and reinforce some of these conclusions. They conclude that while forestry and non-forestry user groups are working well in terms of delivering benefits, they may require additional support in order to be sustainable in the long-run (Alsop and others 2002).

Some authors writing about JFM contend that this program may hurt rather than help poor women and villagers who depend on fuelwood. Sundar (2000) and Sarin and others (1988), for example, argue that JFM, by closing off access to certain forests, helps well-off villagers who can secure alternate sources of fuelwood but burdens poor villagers. Agarwal (2001) focuses on 'participatory exclusion' of women within JFM regimes. ${ }^{9}$ She finds that women bear significant costs associated with loss of access to forests, additional time spent to collect fuelwood and fodder, use of alternate inferior fuels, scarce supply of fuelwood even after forests have regenerated, and inequitable distribution of community benefits. Agarwal argues that participatory exclusion is a broad phenomenon in South Asia and is found in many traditional and new collective action efforts.

In an excellent and broad review of Joint Forest Management, Khare and others (2000), show that JFM has been very successful in spreading rapidly and has been widely implemented in India. They suggest that JFM is resulting in improved forest cover and its potential for timber harvesting is being slowly realized (particularly in West Bengal). JFM has resulted in legitimizing people's use of forests and in village development through the use of JFM related funds - however, Khare and others (2000) contend that this is true in some and not most cases. Many challenges remain. Forest departments tend to

\footnotetext{
${ }^{8}$ For instance in UP, the JFM order of 1997 required the existing Van Panchayats to accept in writing that the Panchayat rules no longer apply under JFM (Khare and others, 2000).

${ }^{9}$ Agarwal (2001) bases her work on 87 community forestry groups in 5 states in India and two districts in Nepal.
} 
view JFM as a tool to protect or rehabilitate millions of hectares of degraded forests, while village communities see it as a means to meet scarce needs and to increase income.

Communities are also heterogeneous and have different requirements, often resulting in conflicts. Further, VFIs seem to function better when JFM is implemented along with wage employment in forest management, and, where there are budgetary allocations for villages. Thus, for more effective VFIs, Khare and others (2000) recommend that short term returns, access to alternative fuel sources prior to forest closure, and intra-community equity issues need to be addressed.

The vast literature on community forestry in India helped us understand how communities organize to manage forests collectively and what the relationship is between fuelwood collection and participation in forest management. We exploit this understanding in our analyses.

\section{Data}

We use data from the fifty-fourth round of India's National Sample Survey (NSS), undertaken between January and June of 1998. The fifty-fourth round was the first national survey in which household and village level information was collected regarding common property rights and resources in India. The survey focused only on rural India.

Though the scope of the fifty-fourth round of NSS was national, we focus on five large states. These are Andhra Pradesh (AP), Madhya Pradesh (MP), Orissa (OR), Uttar Pradesh (UP), and West Bengal (WB). These are the states with the largest number of community forest management groups in 1998. ${ }^{10}$ These are also states for which reasonable data were available in the national sample survey. JFM started officially around 1990 - thus, on average, our secondary data is likely to be picking up villages where CF has been prevalent for some five years. In states such as West Bengal, where CF originated in the 1980s, and in Orissa and Uttar Pradesh, which have large numbers of traditional forestry institutions, we can assume that community forestry has been prevalent for a much longer term.

The NSS collected village and household level information. Village level information was obtained from local officials and knowledgeable persons, including but not limited to local revenue and forest department officials. Our sample includes 524 villages from the five states. From each village, roughly 16 households were randomly identified and surveyed for socio-demographic characteristics, forest dependence and participation in forest management. Thus, our household sample size is 8,307 households.

The main variable of interest at the village level is the existence of a forest management body in the village. The village level questionnaire asks the question "Is there any local forest management body like JFM, Van Panchayet etc.?" This information collected at the village level is distinct from household participation in forest management activities. Our

\footnotetext{
${ }^{10}$ According to figures presented by Khare and others (2000, figure 5.1, p. 83), in 1988, AP had a little less than 5,000 village forest institutions, MP approximately 8,500 VFIs, Orissa more than 5,000 VFIs, UP some 4,000 VFIs, and West Bengal some 3,000 VFIs.
} 
data shows that it is possible for a village not to have a forest management body and yet households living in the village may participate in forest management. On the other hand, not all the households sampled living in a village with forest management body, participate in forest management.

We use four measures to identify the quantity and quality of forest resources -- total government forest area in hectares, total village common land in hectares, a dummy if the village had any forests within the village, and a dummy if a village had forests outside its boundary that was accessible. The relative scarcity of fuelwood was measured by village level fuelwood price aggregated from household level reported quantities and values of fuelwood collection, consumption and sale. We also create a variable of CF intensity, which measures proportion of sampled households that are CF participants in a village.

Our main variable of interest at the household level is a participation dummy for households who report that they are members of a community based forest management organization. The question asked was "Whether the household or any of its members has membership in a local body involved in Joint Forest Management / Van Panchayat?" The survey defined CF to include traditional local groups (NSSO, 1999). Thus, members of any community based forest management organization may respond positively to this question. Further, some households sampled from a CF village may respond negatively to the participation question even where membership was automatic. Thus, we interpret the response to the question of a household being a member of a community forest management program to be an indicator of participation rather than an indicator of membership.

Another key household variable is annual fuelwood consumption by the household. Separate questions were asked regarding fuelwood consumption during last the 365 days from (1) village common/ panchayat land, (2) village forests and van panchayat forests (3) government forests and (4) other locations. We aggregate fuelwood consumption from these four separate sources. In general fuelwood consumption needs are met by households' own collection. ${ }^{11}$ State regulations vary in terms of defining fuelwood and the purpose for which it may be collected. Some states allow sale of collected fuelwood while others do not. ${ }^{12}$

Data on the Level of education of each household member were collected in the survey from a different set of sample households as compared with the households surveyed for common property resources. Thus, the household data on education could not be used

\footnotetext{
${ }^{11} 68$ percent of households collected fuelwood and 2.5 percent sold some fuelwood. Less than one percent of household did not collect any fuelwood but consumed some during the year before survey.

${ }^{12}$ For example, in UP the JFM rules indicate fallen fuel may be collected only for bona fide domestic use (GOUP 1997). In Orissa, government document states that "...brush wood, fallen lops, tops, twigs used as fuelwood shall be available to the members free of costs (GOO 1993)." However, sale of fuelwood is not ruled out in Orissa and MP. In MP, revenue for fuelwood sale is to be shared with the village forest committee (GOMP 1996). In WB, collection of fallen twigs is allowed free of royalty. Members of scheduled tribes enjoy extra rights and privileges granted by the state government in 1981. These rights may not be curtailed by the JFM committees (GOWB 1990).
} 
directly. ${ }^{13}$ Instead, we proxy education by a literacy indicator about whether or not a member of the household reads the newspaper.

Appendix tables A1 and A2 present data on the differences in various village and household characteristics between participants in community forestry and non-participants. The typical participant in community forestry is a poor household that lives on the fringes of forests (see Table A.2). Over half the participating households are agricultural laborers, while only $3 \%$ are headed by females. Eleven percent of these households have at least 1 literate member. Some $38 \%$ of participants belong to scheduled tribes, $7 \%$ to scheduled castes and another 39\% to other backward classes. Participant households, on average, own less than 1 ha of land, but $22 \%$ own an asset such as a radio or TV or telephone.

\section{Methodology}

Our paper seeks to answer two key questions: a) What are the determinants of participation at the village and household levels in community forestry? and, b) What are the impacts of participation on household fuelwood consumption?

We treat domestic consumption of fuelwood as an indicator of dependence on forest resources for subsistence as well as a measure of household welfare. Household and village participation in $\mathrm{CF}$ affect fuelwood use. This relationship exists because in some cases community forestry restricts forest use, and, in other cases, it results in forest management activities that increase access to fuelwood. Further, households that are dependent on scarce fuelwood are more likely to participate. Thus, we model jointly household fuelwood consumption and participation in $\mathrm{CF}$.

In the following paragraphs, we first discuss the determinants of village level participation in community forestry. This is followed by a discussion of household participation and impacts on fuelwood consumption. We use three methods to assess impacts - simple comparison of means, maximum likelihood estimation, and propensity score matching.

\section{A. Probit Model of Village Participation}

There is considerable theoretical and empirical literature on conditions for durable commons institutions and why cooperation in managing natural resources occurs in some cases and fails in others. Agrawal (2001), for example, identifies 24 conditions (see Table 1) based on three synthesis books by Wade (1988), Ostrom (1990) and Baland and Platteau (1996). This literature has greatly improved current understandings of common property institutions and helped promote decentralization in natural resource management. We have built on this literature in our model of why a village may choose to participate in community forest management. Our analysis is in the tradition of many other empirical papers that use forest groups as a unit of analyses to understand cooperative behavior (Heltberg 2001, Varughese and Ostrom 2001).

\footnotetext{
${ }^{13}$ The $54^{\text {th }}$ round of National Sample Survey of India included two household questionnaire modules that were asked to different households.
} 
In our analyses, we consider the decision of a village to engage in a community forestry program to be influenced by three types of variables, state, village, and households. First, different state forest policies may differentially influence village decisions participate in community forestry. Second, village stock of forests, infrastructure and availability of public service may also influence the decision of a village. Finally, characteristics of the residents themselves such as prior experiences with other community based organizations, education and leadership qualities, social diversity, and dependence on forest resources are likely to influence the decision to collectively manage resources. These are factors that are often identified in the commons literature as being useful for understanding cooperation.

We estimate the probability of a village to be in a community forestry program by a probit model written as:

$$
\operatorname{Pr}(J V=1)=\Phi\left(c+c_{1} V+\eta\right)
$$

where $J V$ is an indicator variable for $\mathrm{CF}$ village and $V$ is a vector of village characteristics and $\eta$ is the error term. The independent variables used in the estimation of (1) and the reasons for using them are discussed below.

We use four state dummies, Andhra Pradesh (AP), Madhya Pradesh (MP), Uttar Pradesh $(U P)$, and West Bengal (WB) taking value one if a village is located in that state and zero otherwise, to test for differences in state geography and policies. Orissa (OR) is the default dummy. Forest Dummy takes the value one if the village reports forests within its jurisdiction. We expect the Forest Dummy to have a positive coefficient as villages with access to forest resources are more likely to join the community forestry programs. Villages with access to forests outside the village boundaries may join CF to protect their own forests and degrade outside forests for domestic use. We test this hypothesis by including Forest outside village in our analysis as a dummy variable. A significantly positive coefficient for this variable would imply villages with access to outside forests are more likely to join CF as compared with those with no access to outside forest. Majority fuelwood dependent is a dummy with value one if the village reported that the majority of the households use fuelwood. Our data does not permit us to test for endogeneity of fuelwood dependence at the village level.

There is considerable literature on access to markets and its impacts on common property institutions (Agrawal 2001). Access to markets and increased opportunities for labor and resource exchanges outside the village are generally believed to make cooperation a less desirable strategy. Thus, we expect better access to external markets, as measured by the all weather road dummy, to reduce forest dependence and make CF in the village less likely.

Higher presence of public service offices, measured by Post Office, should make a village participating in CF more likely. Higher leadership capacity of the village, measured by middle school education, and, existence of other self-help groups in the village should also make CF more likely in a village. A village where majority of households are fuelwood dependent is more likely to engage in CF. Thus, we hypothesize that the coefficients of these variables are positive. The Land Gini coefficient measures economic inequality. 
Residents of a village with unequal land distribution are expected to find it more difficult to take collective action. ${ }^{14}$

We test the hypotheses of institutional social discrimination against scheduled tribes, scheduled castes, and other backward classes. Proportion ST, proportion SC, proportion $O B C$ are proportions of respective social groups within the village. If a disadvantaged social group, say scheduled caste, is institutionally discriminated against, we would expect a village with a higher proportion of scheduled caste household would be less likely to be a $\mathrm{CF}$ village. We test whether the coefficient of proportion of SC is negative and significant. Similarly we test for discrimination against proportion of ST and proportion of OBC. ${ }^{15}$

Note that there may be considerable time lag between the CF village selection decision and our data. Particularly for traditional CF, a village may have decided on CF many decades before the survey. The selection of state-initiated CF village may have taken place three to five years before the survey. As a result, the initial conditions such as the quality of forest at the time of $\mathrm{CF}$ village selection may not be true at the time of survey. Thus, we interpret our analyses as estimating the relationship between willingness to engage in collective action and various exogenous factors.

\section{B. Evaluating the Impacts of Participation on Fuelwood Consumption}

We are interested in two related decisions made by rural households: whether to participate in CF activities, and how much fuelwood to consume. These two decisions are interlinked. To evaluate the impact of participation we focus on the question how much does fuelwood consumption change because of the participating households' decision to participate in CF. To answer this question we need to know how much fuelwood a participating household would have consumed if it did not participate. However, the answer to this hypothetical question is not observable in the data. So we construct matching comparison groups of non-participant households to estimate the answer.

The accuracy of the quantified impact of participation depends on how the comparison group is constructed. Let $\alpha_{i}$ be the true impact of household participation on fuelwood consumption.

$$
\alpha_{i}=F_{1 i}-F_{0 i}
$$

where $F_{1 i}$ is fuelwood consumption if household $i$ participates in CF and $F_{0 i}$ is fuelwood consumption if household $i$ chooses not to participate. However, since a household cannot both be participant and non-participant at the same time, we cannot observe the true impact

\footnotetext{
${ }^{14}$ The empirical literature on the impact of heterogeneity on collective action is ambiguous (Agrawal 2001). Baland and Platteau (1996), for example, conclude that heterogeneity of endowments may lead to improved natural resource management but heterogeneity of interests and identity may have the opposite effect. In general, this is an issue that remains to be resolved.

${ }^{15}$ We also constructed a social heterogeneity index based on the proportion of households belonging to various social groups to test for the effect of heterogeneity on collective action - these results are presented in the Appendix.
} 
of participation on fuelwood consumption. Instead, the observed fuelwood use of household $i$ can be expressed as:

$$
F_{i}=J_{i} F_{1 i}+\left[1-J_{i}\right] F_{0 i}
$$

where $J_{i}=1$ if household $i$ is participant in $\mathrm{CF}$ and zero otherwise. Given the impossibility of observing the true impact of participation in fuelwood consumption, the goal is to get an unbiased estimator of $\alpha$ for the average household.

In the following paragraphs, we consider three measures of estimates of $\alpha$. The first is the simple difference in mean fuelwood consumption between participating and nonparticipating households. The second is the joint maximum likelihood estimator (MLE) measure of $\alpha$. And the third is the propensity score based measure of $\alpha$. Further details on evaluation methods for non-experimental data can be found in Ravallion (2001), and, Blundell and Costa Dias (2000).

\section{$\underline{\text { Comparison of Mean Differences between Community Forestry Groups }}$}

This method essentially involves comparing the mean fuelwood consumption between two groups of households and villages: those participating in community forestry and the nonparticipants. The differences in mean consumption between the two groups is expected to capture the impact of participation. A significant t-test suggests that community forestry increases mean consumption and household welfare. However, while mean comparisons are useful, they could simply be an artifact of proximity to forests or other household and village characteristics. Thus, in the following sections we try to control for differences between participant and non-participants and then assess impacts.

\section{$\underline{\text { MLE Measure of Household Participation and Fuelwood Consumption }}$}

The mean difference between participants and non-participants would be an unbiased estimator of $\alpha$ if participant households were randomly selected. However, we know that participation is voluntary and self-reported. We control for observable household and village characteristics so that the impact of CF participation is conditioned on observables. Second, some of the factors that help a household decide whether to participate, also determine the level of fuelwood consumption. Thus, we treat participation and fuelwood consumption as jointly determined and then test to see if this hypothesis is valid.

Consider the level of household participation in CF to be a function of a vector of exogenous covariates and a random component $\varepsilon$.

$$
J_{i}^{*}=b+b_{1} H_{i}+b_{2} V_{i}+\beta_{1} P J_{i}+\beta_{2} J V_{i}+\varepsilon_{i}
$$

where $H$ is a vector of household characteristics other than household size, $V$ is a vector of village characteristics, $J V$ is a $C F$ village indicator variable taking value one if CF village and zero otherwise, and, $\mathrm{PJ}$ is proportion of $\mathrm{CF}$ participant households in the village measuring the peer effect of participation. However, note that the level of participation is not observed. Instead, the binary observed household participation decision is 


$$
J_{i}= \begin{cases}1, & \text { if } J_{i}^{*}>0 \\ 0, & \text { otherwise }\end{cases}
$$

The CF participation and fuelwood consumption equations may then be written as :

$$
\begin{gathered}
\operatorname{Pr}\left(J_{i}=1\right)=\Phi\left(b+b_{1} H_{i}+b_{2} V_{i}+\beta_{1} P J_{i}+\beta_{2} J V_{i}+\varepsilon_{i}\right) \\
F_{i}=a+a_{1} H_{i}+H S_{i}+a_{2} V_{i}+\alpha J_{i}+\alpha_{2} J V_{i}+e_{i}
\end{gathered}
$$

where HS refers to household size, and $e$ and $\varepsilon$ are bivariate normal with mean zero and covariance matrix:

$$
\left[\begin{array}{ll}
1 & \rho \\
\rho & \boldsymbol{\sigma}_{\mathbf{e}}
\end{array}\right]
$$

We estimate robust standard errors to take into account heteroskedasty arising from omitted variables of village heterogeneity.

The correlation coefficient $\rho$ accounts for the possibility that fuelwood consumption and CF participation decisions are jointly made by households. To test this hypothesis we jointly estimate (5) and (6). ${ }^{16}$ The rationale of this estimator is to control directly for the part of the error term in (6) that is correlated with household participation in $\mathrm{CF} .{ }^{17}$ This estimator also maximizes the likelihood function and is known as the maximum likelihood estimator. The iterative process used allows us to estimate $\rho$ and to test the hypothesis $\rho$ $=0$. We report results from the maximum likelihood estimations, as well as probit estimates of (5) and OLS estimates of (6) for comparison.

\section{Determinants of Household Participation and Fuelwood Consumption}

In this section, we discuss the choice of the independent variables in equations (5) and (6). Equation (5) estimates the determinants of household participation. Similar to the village level equation, in equation (5), we hypothesize that household participation depends on institutional design and forest policies that differ by state, resource indicators, village infrastructure, household specific social and economic characteristics, and whether there are others in the village that also participate in community forestry.

Andhra Pradesh, Madhya Pradesh, Uttar Pradesh, and West Bengal are state dummies taking value one for households in these states. The state dummies represent differences in rules that affect the perception of costs and benefits of participation. To some extent, they capture differences between traditional and historical community forestry institutions (UP and Orissa) and state supported institutions (AP, MP and WB).

\footnotetext{
16 There are many variations of this model in the literature. We implement Maddala's (1983) version.

${ }^{17}$ The two step iterative procedure works as follows. In first step the part of $e$ that is correlated with $J$ is estimated from (5). It is then included in (6) and the effect of participation on fuelwood consumption is estimated in the second step. By construction, the error term of the modified equation (6) estimated in the second step is not correlated with the participation decision. The second step provides new estimates of $e$ and the two steps are repeated until the system converges.
} 
We use two indicators to measure resource stock, total area under government forests and total area under village common land. The all weather road dummy takes value one if such a road exists within the village - all weather road is a proxy for access to market and fuel substitutes.

Fuelwood price measures relative scarcity of fuelwood at the village level. We hypothesize that resource scarcity increases the probability of participation. Fuelwood price is endogenously determined by village level fuelwood stock, demand for fuelwood, and availability of substitutes. Thus, it is likely to be correlated with other village level variables such as total area under government forests and all weather road. When used as an independent variables in (5) and (6), fuelwood price can result in multicolinearity with other village level variables. Typically multicolinearity results in unbiased coefficients but larger standard errors. We do not find any significant correlation between fuelwood price and other village level variables. The estimated standard errors of the village level variables are small enough to make the corresponding coefficients statistically significant. Thus, we conclude multicolinearity is not a significant problem in our estimations.

The endogeneity of village level fuelwood price and its relationships with unobserved village characteristics such as forest cover density may result in clustered heterogeneity of the error terms of (5) and (6). That is, the standard errors of the error terms are likely to be different for each village. To correct for this possibility we calculate robust standard errors adjusted for village level clustering.

Household characteristics likely to influence participation are wealth, education, occupational and caste categories, and age. We proxy household wealth by asset index. The asset index is constructed from the hectares of land possessed by the households and ownership of phone, radio, and TV. The construction of the asset index is based on Filmer and Pritchett's (2001) methodology. Wealth is expected to have an ambiguous effect on participation. If $\mathrm{CF}$ is perceived to increase long-term returns to participation, then wealth will likely increase the probability of participation. However, if CF is perceived to increase short-term returns to participation, the sign on the wealth measure is likely to be negative.

We use a number of other variables to control for household level characteristics. The variable read newspaper takes the value one for those households where newspapers are read. The variable fuelwood used for consumption and enterprise takes the value one for those households that use fuelwood for domestic consumption and as input to family enterprise. The dummy variables self employed in non-agriculture, agricultural labor, nonagricultural labor, and other nonagricultural occupations take the value one for households that report the respective occupational type. The reference group is 'self employed in agriculture'. The variable female headed households takes the value one for those households with female heads. Schedule Tribe, Schedule Caste, and Other Backward Class are variables that take the value one for households in respective social groups.

The proportion of sampled households in a village participating in CF is measured by $P J$. This measures the effect of peer pressure on participation. Higher peer pressure may make 
participation in CF more likely for a household. However, peer pressure to participate in CF should not have any direct effect on fuelwood consumption. ${ }^{18}$ Similarly, $H S$ or household size has a direct effect on fuelwood consumption. Larger households is likely to need more fuelwood. However, household size does not directly influence participation. Thus, inclusion of $P J$ in (5) and not in (6) and inclusion of $H S$ in (6) and not in (5) helps identify both the equations.

Now we turn to consumption of fuelwood or equation (6). Consumption of fuelwood is a function of state dummies, reflecting differences in state fuelwood policies, household characteristics, scarcity indicators, including fuelwood price, a dummy to capture program effects i.e. village participation in $\mathrm{CF}$, and a dummy to capture household participation in $\mathrm{CF}$.

Agricultural labor households are expected to consume more fuelwood, while households in non-agricultural occupations are likely to have access to other sources of fuel. We hypothesize that indicators of wealth and literacy have a negative effect on fuelwood consumption. Fuelwood is an inferior good -- as a household's income and wealth increases, it is likely to switch to other more clean fuels. Age and female headed status of the household are hypothesized to have a negative impact on consumption. This is because consumption is closely tied to collection and we expect older and female dependent households to collect less. On the contrary, households with more members will consume more.

Fuelwood prices reflect local scarcity. Thus, we expect the usual negative relationship between prices and demand even if markets for fuelwood are thin. ${ }^{19}$ We use two other measures of resource scarcity - total government forest land and village common landwe expect these to be positively associated with consumption.

The signs of $\mathrm{CF}$ village and participation dummies are empirically determined. We assume $\mathrm{CF}$ village selection is exogenous to fuelwood consumption and use it as one of the independent control variables in household consumption of fuelwood (6) and CF participation (5). This assumption is motivated by the fact that our data was collected approximately five years after CF was instituted as a government approved program, and, in Orissa and Uttar Pradesh, community forestry started before that. As a result, initial condition such as depleted forest resources that lead a particular village to embrace $\mathrm{CF}$ may not be true during the survey. We also note, not all CF participant households reside in $\mathrm{CF}$ villages. To the extent that $\mathrm{CF}$ villages have been able to regenerate forests, we expect a positive relationship. However, if regeneration has not resulted in opening up of closed forests for fuelwood collection, then the relationship can be negative.

\footnotetext{
${ }^{18}$ It is possible that peer-pressure has an indirect effect on consumption by affecting fuelwood supply. However, we found no correlation between peer-pressure and consumption.

${ }^{19}$ While fuelwood prices are endogenous at the village level, at the household level, fuelwood prices are exogenous to consumption decisions. That is, a single household cannot change fuelwood price by its own fuelwood consumption decisions.
} 
We hypothesize that participation can increase consumption of fuelwood. If households that participate have access to forest management activities such as clearing or lopping trees, then they may be able to procure and consume more fuelwood. Better knowledge of rules and regulations and access to leaders would also enable greater collection and consumption.

\section{Propensity Score Based Matching}

Our third technique to evaluate the impact of participation, propensity score matching, is based on identifying a comparison group similar to participants. If we have a comparison group that mimics the group of participant households well, the comparison group is a good proxy for the counterfactual. To identify the comparison group of non-participants we use propensity scores based on (5). To match participant households with nonparticipant households, we use three alternate methods: nearest method, radius matching, and Gaussian kernel weighted matching. We also match participant villages with nonparticipant villages.

In nearest neighbor matching, a participating household (or village) is matched with a nonparticipating household with the closest propensity score. In radius matching participating households are matched with nonparticipating households that have propensity score within 0.1 radius of the propensity score of the participating households. Kernel matching method uses weighted average of information from all the non-participating households to arrive at the counterfactual for each participating households. The weights are based on Gaussian kernel.

In all cases we only used households with propensity score in the common support range to identify the comparable non-participating households. The standard errors were bootstrapped to determine the statistical significance of the differences in fuelwood consumption between participating and non-participating households.

\section{Results}

In this section we outline the results on village and household participation and their determinants as well as the impact of participation on fuelwood consumption.

\section{A. Village Participation in Community Forestry}

The summary statistics of the village level variables used are in table 1 . The mean column for the dummy variables represent the proportion of villages where that dummy variable takes the value one. For example, 8 percent of the 524 villages report presence of $\mathrm{CF}$, while 43 percent report having government forests within the village. In an average village, 19 percent of the sample households belonged to the social group of scheduled tribe and 37 percent of the villages reported that majority of the residents depended on fuelwood as fuel. 
The estimation results of village level participation are in table 2. Only three variables are significant in explaining village level participation - villages with government forests within village boundaries, villages with at least one member with middle school or higher education, and, villages where the majority of households are dependent on fuelwood. The positive and significant relationship of the three indicators with the probability of participation is expected.

Explanatory variables that are not statistically significant in explaining the probability of CF participation are important too. For example, anecdotal evidence suggests villages with access to forests outside their boundary may choose to protect their own forests and exploit those outside. Thus, such villages may be more likely to participate in the CF program. However, our results do not support this hypothesis.

Villages with access to markets and government services represented by all weather roads and post offices may be more likely to participate in CF program if the program is implemented in more accessible areas. This has been shown to be the case in the CF program in Nepal. Further, theory suggests that the existence of self-help groups within a village may make the community experienced in community based organizations and make participation in CF program more likely. Our results do not support either of these notions.

The hypothesis of institutional bias suggests government officials may not promote CF in villages with higher proportions of disadvantaged social groups such as scheduled tribes, scheduled castes, and other backward classes. Though the coefficient of the proportion of scheduled caste households in a village is negatively related to the probability of participation, it is not statistically significant. Thus, our results do not support the hypothesis of institutional bias against these social groups. We also find that the presence of VFIs cannot be explained by economic or social heterogeneity. ${ }^{20}$

\section{B. Determinants of Household Participation in Community Forestry and Fuelwood Consumption}

Table 3 presents the standard descriptive statistics of the variables used in (5) and (6). Table 4 shows the estimation results of (5) estimated as probit in a single equation and as part of a joint estimation of the two equation system. The Wald test of independence of equations (5) and (6) cannot accept the independence hypothesis at better than one percent level. This confirms our intuition that (5) and (6) are not independent and MLE estimation is appropriate.

\footnotetext{
${ }^{20}$ We also tested the hypothesis that social heterogeneity in the village hinders CF group formation by constructing an index of social heterogeneity based on proportions of households of ST, SC, OBC, and other groups. Appendix table A.3 shows estimation of village level participation with social heterogeneity as one of the determinants. We find the coefficient of social heterogeneity of the expected sign but statistically not significant.
} 
The MLE estimation results for (5) can be summarized as factors that make participation of a household in CF less likely and those factors that make participation more likely. We cannot reject the following hypotheses regarding factors that make CF less likely for a household: (a) households that use fuelwood for domestic and entrepreneurial purposes are less likely to participate in $\mathrm{CF}$; (b) households reporting non-agricultural labor as the main occupation are less likely to participate in CF; (c) schedule caste households are less likely to participate in $\mathrm{CF}$; and, (d) households that live in village with more village common land are less likely to participate in CF.

As expected, we find that the probability of participation in CF increases where fuelwood prices are higher, reflecting local scarcity; at least one household member reads a newspaper, and there is a higher proportion of CF households in the village, indicating knowledge and peer group effects.

Table 5 shows the results of (6) estimated as a single regression (OLS) as well as jointly estimated with (5) (MLE). The most important results of this paper regarding CF on fuelwood consumption are presented here. We find that households residing in CF villages consume as much fuelwood as those residing in non-CF villages. However, households that participate in CF consume significantly more fuelwood as compared with the households that do not participate. This implies the CF program does not benefit all residents of the $\mathrm{CF}$ village in terms of higher fuelwood consumption. However, the program does benefit the participant household. Since CF participant households consume more fuelwood, we conclude that these households have greater access to fuelwood as compared with households who do not participate in the CF program.

Among other factors that determine fuelwood consumption, household occupation plays a role. As compared with households self employed in agriculture, the agricultural labor households consume more fuelwood and households in other non-agricultural occupations consume less. Given different opportunity costs of fuelwood collection, the differences in fuelwood consumption between different occupational categories are expected.

Scheduled tribes is the only disadvantaged social group that consumes significantly more fuelwood as compared with the general sample. This confirms the hypothesis that scheduled tribes are more dependent on forest resources for their subsistence as compared with others.

Ownership of land, phone, radio, and TV reflect greater wealth of the households. The asset index is based on the principal components of these assets and is associated with lower consumption of fuelwood. Education reflected by readers of newspaper in the households may increase the opportunity costs of fuelwood collection and has a negative relationship with fuelwood consumption.

We tested the hypothesis that female headed households are discriminated against participating in CF and found no evidence of it. Similarly we find the female headed households do not consume significantly less fuelwood as compared with their male headed counterparts. Households with more members consume more fuelwood. 
The coefficient of fuelwood price is negative, large, and statistically significant. Thus, we cannot reject the hypothesis that the village fuelwood price reflects relative fuelwood scarcity. Total government forest and total village common are both sources of fuelwood, and, larger areas may reflect larger supply of fuelwood (given forest quality). We find that households in villages with larger forest and village commons consume more fuelwood.

\section{Impact of Participation on Fuelwood Consumption}

The first part of table 6 identifies simple mean differences in fuelwood consumption between participating and non-participating households and villages. Our results show that households who report that they participate in community forestry consume almost 260 kgs more fuelwood than households that do not participate. This difference is statistically significant. Further, average fuelwood consumption in villages that are CF villages is 27 percent greater than that in non-CF villages. Among CF participants, households that do not read newspapers consume four times more fuelwood as compared with households that read newspapers. Among participating households, ST, SC and OBC households consume 16 percent less fuelwood as compared with other social groups.

Because participants and non-participants are not randomly selected, we know that the results from the comparison of simple means are biased. A superior estimate is the MLE estimate based on multivariate analysis of participation and consumption decisions. The second part of table 6 re-states the results from the MLE estimates. It shows that households who participate in community forestry consume $744 \mathrm{kgs}$ of fuelwood more than the non-participant households. At the same time, the effect of village participation in $\mathrm{CF}$ is insignificant.

The third part of table 6 shows the average effect of household and village participation in CF on fuelwood consumption. Results of three matching methods, nearest neighbor, radius, and kernel weighted are reported. This effect is positive and significant when participating households are matched with non-participating households using the radius method. Thus, this result supports the MLE result that household participation in community forestry has a positive and significant effect on household fuelwood consumption. The average change in fuelwood consumption that can be attributed to $\mathrm{CF}$ at the village level is not statistically significant in any of the three methods. This result also supports the result based on MLE.

\section{Conclusions}

Our goal in this paper is to understand why certain Indian villages and households participate in community forestry while others do not, and to obtain an answer regarding the welfare impacts of decentralized forest management. Because of the availability of data, we use fuelwood consumption as an indicator of forest use as well as household welfare. This is a reasonable indicator - most poor rural households are fully dependent on fuelwood for their energy needs. 
We find that the incidence of village forest institutions can be explained by their obvious proximity to forests, the presence of an educated person in the village, and a clear dependence on fuelwood. Our results reinforce traditional wisdom that local leadership is critical for collective action institutions to begin and be sustained. They also highlight the importance of fuelwood as an impetus for community forestry.

An interesting policy finding is that a household in MP and UP is more likely to participate in community forestry relative to a household in Orissa. Thus, forest policies in these two states seem to better facilitate CF participation. Another key result is that scarcity is strongly correlated with participation. JFM has, in its second phase, expanded to nondegraded forests as well as degraded forests. While this is generally considered a good idea, our findings suggest that some caution needs to be exercised in rapidly advancing JFM to areas where scarcity may not be such a large issue.

Our most important findings are that fuelwood consumption and participation are linked and participation has a significant positive impact on consumption. Village participation has a positive but insignificant effect. This is a very interesting finding. It suggests that JFM and other forms of community forestry are benefiting participants in the short to medium term. However, these benefits cannot really be called program benefits because the presence of the program at the village level does not seem to matter. We think that participants benefit because they are able to take part in forest related activities and/or because they are better informed about rules and regulations. Our results also do not support any negative impacts of community forestry programs on fuelwood consumption.

Finally, we acknowledge that JFM, the state-initiated community forestry program, has changed in important ways in the last five years. Formerly nationalized NTFP revenues and medium-term timber benefits are now accruing to village communities. The number of JFM communities has also expanded. Thus, our results, which focus on fuelwood consumption in 1998, are indicative of impacts but do not present the full picture. Further, the effect of people's use of natural resources on forests can change over time, depending on markets and institutions as well as the resilience of forests themselves. In order to probe these dynamic effects, we would need time-series data. Future studies would benefit tremendously from carefully obtained base-line surveys and time-series information. 


\section{References}

Agarwal, B. 2001. "Participatory Exclusions, Community Forestry, and Gender: An Analysis for South Asia and a Conceptual Framework." World Development 29 (10): 1623-1648.

Agrawal, A. 2001. "Common Property Institutions and Sustainable Governance of Resources." World Development 29 (10):1649-1672

Alsop, R., D. Sjoblom, C. Namazie and P. Patil. 2002. "Community-level User Groups in Three World Bank-Aided Projects. Do they Perform as Expected?" Social Development Papers, No. 40. The World Bank.

Baland J-M, and J-P. Platteu 1996. Halting Degradation of Natural Resources. Is there a Role for Rural Communities? FAO and Oxford University Press: Oxford.

Ballabh, V. and Balooni, K and Dave, S. 2002. "Why Local Resources Management Institutions Decline: A comparative Analyses of Van (Forest) Panchayats and Forest Protection Committees in India." World Development 30 (12) : 2153-2167

Bardhan, P, J. Baland, S. Das, D. Mookherjee, R. Sarkar 2002. "The Environmental Impact of Poverty: Evidence from Firewood Collection in Rural Nepal" mimeo, 2002

Blundell R., Costa Dias M. 2000. "Evaluation Methods for Non-Experimental Data," Fiscal Studies 21 (4): 427-468.

Chopra and Dasgupta, 2002. "Policy Implication of Common Pool Resource Knowledge in India, Tanzania and Zimbabwe" mimeo Institute of Economic Growth, Delhi, India

Chopra and Dasgupta 2003. "The Nature of Household Dependence on Common Pool Resources: An econometric study for India" Working Paper Series No E/232/2002, Institute of Economic Growth, Delhi India

Edmonds, E. 2002. "Government Initiated Community Resource Management and Local Resource Extraction from Nepal's Forests." Journal of Development Economics 68 (2): 89-115.

Filmer, D. and Pritchet, L. 2001. "Estimating Wealth Effects without Expenditure Data-Or Tears: An Application to Educational Enrollments in States of India," Demography 38 (1):115-32

Government of Andhra Pradesh, 1996. Joint Forest Management Order No. G.O.MS.NO.173,

Government of Orissa, Notification No. 16700-10F (pron) -20/93, 1993 
Government of Madhya Pradesh, Notification No. F.16-4-10-2-91, 1996

Government of Uttar Pradesh, The Uttar Pradesh Village Forest Joint Management Rules, 1997

Government of West Bengal resolution No. 5062-For/D/IS-1688, 1990)

Heltberg, R. 2001. "Determinants and Impacts of Local Institutions for Common Resource Management.” Environment and Development Economics 6: 183-208.

Khare, A., M. Sarin, NC Saxena, S. Palit, S. Bathia, F, Vania, M. Satyanarayana. 2000. Joint Forest Management: Policy, Practice and Prospects. Policy that works for Forests and People Series No. 3. New Delhi and London: World Wide Fund for Nature-India and the International Institute for Environment and Development.

Klooster, D. 2000. "Community Forestry and Tree Theft in Mexico: Resistance or Complicity in Conservation?" Development and Change 31: 281-305.

Kumar, S. 2002, "Does participation in common pool resource management help poor? A social cost-benefit analysis of joint forest management in Jharkhand, India", World Development, 30 (5):

Lise, W. 2000. "Factors Influencing People's Participation in Forest Management in India." Ecological Economics 34: 379-392

Maddala, G.S. 1983 Limited-dependent and Qualitative Variables in Econometrics. Cambridge University Press.

NSSO, 1999, Data Documentation for NSS $54^{\text {th }}$ Round, National Sample Survey Organization, Department of Statistics, Government of India, New Delhi

Ostrom, E. 1990. Governing the Commons. The Evolution of Institutions for Collective Action. Cambridge: Cambridge University Press.

Ravallion, M. 2001. "The Mystery of the Vanishing Benefits: An introduction to Impact Evaluation" The World Bank Economic Review, 15 (1): 115-140.

Sarin, M. with L. Ray, M.S. Raju, M. Chatterjee, N. Banerjee and S. Hiremath, 1988. Who Gains? Who Loses? Gender and Equity Concerns in Joint Forest Management. New Delhi SPWD.

Singh, N. 2002. "Federations of community forest management groups in Orissa: Crafting new institutions to assert local rights." Forests, Tress and People Newsletter 46: 35-45: September 2002. 
Sundar, N. 2000. "Unpacking the 'Joint' in Joint Forest Management." Development and Change, vol. 31, 255-279.

Wily, L. 2002. The political economy of community forestry in Africa- Getting the power relations right. Forest, Tress and People Newsletter 46: 4-12: September 2002.

Varughese, G., and Ostrom, E. 2001. "The Contested Role of Heterogeneity in Collective Action: Some Evidence from Community Forestry in Nepal." World Development 29 (5): 747-765.

Wade, R. 1988. Village Republics: Economic Conditions for Collective Action in South India. Cambridge: Cambridge University Press. 


\section{Tables}

Table 1. Summary statistics of village level variables

\begin{tabular}{|c|c|c|c|c|}
\hline Variables & Mean & $\begin{array}{l}\text { Standard } \\
\text { Deviation }\end{array}$ & Minimum & Maximum \\
\hline CF Village & 0.08 & 0.27 & 0 & 1 \\
\hline Andhra Pradesh & 0.17 & 0.38 & 0 & 1 \\
\hline Madhya Pradesh & 0.20 & 0.40 & 0 & 1 \\
\hline Orissa & 0.27 & 0.44 & 0 & 1 \\
\hline Uttar Pradesh & 0.31 & 0.46 & 0 & 1 \\
\hline West Bengal & 0.06 & 0.23 & 0 & 1 \\
\hline Forest Dummy & 0.43 & 0.50 & 0 & 1 \\
\hline Forest Outside Village Within Reach Dummy & 0.50 & 0.50 & 0 & 1 \\
\hline All Weather Road Dummy & 0.64 & 0.48 & 0 & 1 \\
\hline Post Office Dummy & 0.40 & 0.49 & 0 & 1 \\
\hline Middle School Education Dummy & 0.73 & 0.44 & 0 & 1 \\
\hline Self Help Group Dummy & 0.15 & 0.36 & 0 & 1 \\
\hline Proportion ST & 0.19 & 0.31 & 0 & 1 \\
\hline Proportion SC & 0.24 & 0.23 & 0 & 1 \\
\hline Proportion OBC & 0.30 & 0.28 & 0 & 1 \\
\hline Majority Fuelwood Dependent Dummy & 0.37 & 0.48 & 0 & 1 \\
\hline Gini Coefficient for land possessed in village & 0.51 & 0.17 & 0 & 0.92 \\
\hline
\end{tabular}

Total number of villages 524 


\begin{tabular}{lcr}
\hline \multicolumn{2}{c}{ Table 2. Probit analysis of determination of village level participation in CF } \\
\hline \multicolumn{1}{c}{ Dependent variable: CF Village } & Coefficient & $\begin{array}{c}\text { Standard } \\
\text { Errors }\end{array}$ \\
\hline Constant & $-3.02^{* *}$ & 0.61 \\
Andhra Pradesh & -0.04 & 0.36 \\
Madhya Pradesh & 0.13 & 0.26 \\
Uttar Pradesh & 0.15 & 0.35 \\
West Bengal & $0.76+$ & 0.43 \\
Forest Dummy & $0.86^{* *}$ & 0.24 \\
Forest Outside Village Within Reach Dummy & 0.13 & 0.27 \\
All Weather Road Dummy & 0.11 & 0.22 \\
Post Office Dummy & -0.14 & 0.23 \\
Middle School Education Dummy & $0.58^{*}$ & 0.25 \\
Self Help Group Dummy & 0.17 & 0.30 \\
Proportion ST & 0.01 & 0.49 \\
Proportion SC & -0.61 & 0.60 \\
Proportion OBC & 0.15 & 0.52 \\
Majority Fuelwood Dependent Dummy & $0.96^{* *}$ & 0.28 \\
Gini Coefficient for land possessed in village & -0.29 & 0.61 \\
N & 524 & \\
Log likelihood & -106.68 & \\
Pseudo R squared & 0.25 & \\
\hline Notes: & &
\end{tabular}

Notes: ${ }^{* *}$ significant at 1 percent, ${ }^{*}$ significant at 5 percent, + significant at 10 percent 


\begin{tabular}{|c|c|c|c|c|}
\hline Variables & Mean & $\begin{array}{l}\text { Standard } \\
\text { Deviation }\end{array}$ & Minimum & Maximum \\
\hline Annual Fuelwood Consumption (Kg) & 750.59 & 877.17 & 0 & 20000 \\
\hline Households Participating in CF & 0.02 & 0.13 & 0 & 1 \\
\hline Andhra Pradesh & 0.18 & 0.38 & 0 & 1 \\
\hline Madhya Pradesh & 0.19 & 0.39 & 0 & 1 \\
\hline Orissa & 0.26 & 0.44 & 0 & 1 \\
\hline Uttar Pradesh & 0.31 & 0.46 & 0 & 1 \\
\hline West Bengal & 0.06 & 0.23 & 0 & 1 \\
\hline Fuelwood used for consumption \& enterprise & 0.04 & 0.20 & 0 & 1 \\
\hline Self Employed in Non-Agriculture & 0.10 & 0.31 & 0 & 1 \\
\hline Agricultural Labor & 0.38 & 0.48 & 0 & 1 \\
\hline Non-Agricultural Labor & 0.06 & 0.24 & 0 & 1 \\
\hline Other Non Agricultural Occupation & 0.10 & 0.30 & 0 & 1 \\
\hline Scheduled Tribe & 0.18 & 0.38 & 0 & 1 \\
\hline Scheduled Caste & 0.24 & 0.43 & 0 & 1 \\
\hline Other Backward Class & 0.30 & 0.46 & 0 & 1 \\
\hline Land Possessed (ha) & 0.82 & 1.65 & 0 & 48 \\
\hline Own Phone, Radio, TV Dummy & 0.29 & 0.45 & 0 & 1 \\
\hline Read Newspaper Dummy & 0.13 & 0.33 & 0 & 1 \\
\hline Female Headed Households & 0.07 & 0.26 & 0 & 1 \\
\hline Average Age of Household Members & 26.72 & 11.33 & 5 & 75 \\
\hline Household Size & 5.04 & 2.53 & 1 & 23 \\
\hline Fuelwood Price (Rs/Kg) & 0.75 & 0.32 & 0.10 & 2.86 \\
\hline Total Govt Forest Area (ha) & 70.32 & 252.38 & 0 & 3044 \\
\hline Total Village Common Land (ha) & 74.85 & 207.25 & 0 & 2417 \\
\hline All Weather Road Dummy & 0.65 & 0.48 & 0 & 1 \\
\hline CF Village & 0.08 & 0.27 & 0 & 1 \\
\hline Proportion of CF households & 0.02 & 0.11 & 0 & 1 \\
\hline
\end{tabular}

Total number of households 8307 
Table 4. Household participation analysis, probit and MLE methods

\begin{tabular}{|c|c|c|c|c|}
\hline \multirow[b]{2}{*}{$\begin{array}{l}\text { Dependent Variable: } \\
\text { Households Participating in CF }\end{array}$} & \multicolumn{2}{|c|}{ Probit } & \multicolumn{2}{|c|}{ MLE (Part One) } \\
\hline & Coef. & $\begin{array}{l}\text { Standard } \\
\text { Errors }\end{array}$ & Coef. & $\begin{array}{l}\text { Standard } \\
\text { Errors }\end{array}$ \\
\hline Constant & $-2.74^{* *}$ & 0.24 & $-2.59 * *$ & 0.27 \\
\hline Andhra Pradesh & $-0.52^{* *}$ & 0.17 & $-0.58^{* *}$ & 0.22 \\
\hline Madhya Pradesh & 0.27 & 0.19 & $0.33+$ & 0.18 \\
\hline Uttar Pradesh & $0.32+$ & 0.18 & $0.43^{* *}$ & 0.14 \\
\hline West Bengal & 0.03 & 0.26 & 0.19 & 0.25 \\
\hline Fuelwood used for consumption \& enterprise & $-0.79 * *$ & 0.27 & $-1.03^{* *}$ & 0.24 \\
\hline Self Employed in Non-Agriculture & -0.26 & 0.18 & -0.02 & 0.16 \\
\hline Agricultural Labor & -0.06 & 0.14 & -0.01 & 0.10 \\
\hline Non-Agricultural Labor & -0.34 & 0.24 & $-0.26+$ & 0.13 \\
\hline Other Non Agricultural Occupation & -0.53 & 0.32 & -0.16 & 0.20 \\
\hline Scheduled Tribe & -0.04 & 0.19 & -0.10 & 0.18 \\
\hline Scheduled Caste & $-0.88 * *$ & 0.34 & $-0.59+$ & 0.31 \\
\hline Other Backward Class & -0.08 & 0.12 & -0.06 & 0.10 \\
\hline Asset Index & 0.02 & 0.06 & 0.02 & 0.03 \\
\hline Read Newspaper Dummy & $0.59^{* *}$ & 0.17 & $0.45^{* *}$ & 0.11 \\
\hline Female Headed Households & 0.11 & 0.15 & 0.12 & 0.09 \\
\hline Fuelwood Price (Rs/Kg) & 0.02 & 0.19 & 0.48 ** & 0.19 \\
\hline Total Govt Forest Area ('000 ha) & -0.05 & 0.20 & -0.15 & 0.18 \\
\hline Total Village Common Land ('000 ha) & $-1.07+$ & 0.63 & $-1.27^{*}$ & 0.61 \\
\hline All Weather Road Dummy & -0.15 & 0.13 & -0.14 & 0.11 \\
\hline Proportion of CF households in Village & $5.52^{* *}$ & 0.48 & $3.68^{* *}$ & 1.04 \\
\hline CF Village & 0.03 & 0.28 & 0.11 & 0.23 \\
\hline$N$ & 8307 & & 8307 & \\
\hline Log likelihood & -205.44498 & & $-67553.96^{\#}$ & \\
\hline Pseudo R squared & 0.73 & & & \\
\hline
\end{tabular}

Notes: ${ }^{* *}$ significant at 1 percent, * significant at 5 percent, + significant at 10 percent MLE method estimates CF participation and fuelwood consumption simultaneously.

\# log likelihood ratio of joint estimation. The coefficients of fuelwood consumption are in table 5 .

Wald test of independent equations. $($ rho $=0)$ : chi2 $(1)=7.65$ Prob $>$ chi2 $=0.0057$ 


\begin{tabular}{|c|c|c|c|c|}
\hline \multirow[b]{2}{*}{$\begin{array}{c}\text { Dependent Variable: } \\
\text { Annual Fuelwood Consumption }\end{array}$} & \multicolumn{2}{|c|}{ OLS } & \multicolumn{2}{|c|}{ MLE (Part Two) } \\
\hline & Coef. & $\begin{array}{l}\text { Standard } \\
\text { Errors }\end{array}$ & Coef. & $\begin{array}{l}\text { Standard } \\
\text { Errors }\end{array}$ \\
\hline Constant & $1043.67^{* *}$ & 118.49 & $1056.83^{* *}$ & 120.33 \\
\hline Andhra Pradesh & $-251.87^{* *}$ & 78.79 & $-248.52^{* *}$ & 79.11 \\
\hline Madhya Pradesh & $-324.66^{* *}$ & 82.35 & $-320.95^{* *}$ & 82.66 \\
\hline Uttar Pradesh & $-530.83^{* *}$ & 80.05 & $-523.15^{* *}$ & 79.59 \\
\hline West Bengal & $-444.41^{* *}$ & 94.88 & $-447.61^{* *}$ & 95.09 \\
\hline Fuelwood used for consumption \& enterprise & 209.25 & 130.89 & 211.48 & 132.80 \\
\hline Self Employed in Non-Agriculture & -35.85 & 51.20 & -37.23 & 51.22 \\
\hline Agricultural Labor & $109.29 * *$ & 32.44 & $101.27^{* *}$ & 33.20 \\
\hline Non-Agricultural Labor & 59.08 & 69.16 & 63.22 & 69.07 \\
\hline Other Non Agricultural Occupation & $-165.88^{* *}$ & 46.95 & $-163.00 * *$ & 47.05 \\
\hline Scheduled Tribe & $151.20 *$ & 74.08 & 146.42 * & 74.50 \\
\hline Scheduled Caste & 38.64 & 51.73 & 42.87 & 51.62 \\
\hline Other Backward Class & 5.46 & 54.35 & -3.70 & 54.47 \\
\hline Asset Index & -40.84 ** & 14.85 & -40.82 ** & 14.93 \\
\hline Read Newspaper Dummy & $-242.48^{* *}$ & 44.75 & $-242.68 * *$ & 44.40 \\
\hline Female Headed Households & -53.36 & 34.69 & -51.90 & 34.66 \\
\hline Average Age of Household & -0.38 & 0.89 & -0.53 & 0.88 \\
\hline Household Size & $52.63 * *$ & 6.32 & $50.33^{* *}$ & 6.51 \\
\hline Fuelwood Price (Rs/Kg) & $-398.35^{* *}$ & 71.83 & $-400.42^{* *}$ & 72.72 \\
\hline Total Govt Forest Area (ha) & $0.22 *$ & 0.11 & $0.25^{*}$ & 0.12 \\
\hline Total Village Common Land (ha) & $0.21^{*}$ & 0.10 & $0.22 *$ & 0.10 \\
\hline All Weather Road Dummy & -37.58 & 48.51 & -36.51 & 48.80 \\
\hline CF Village & 59.76 & 101.95 & -81.32 & 115.45 \\
\hline Households Participating in CF & 28.82 & 109.98 & $744.05^{* *}$ & 228.73 \\
\hline$N$ & 8307 & & 8307 & \\
\hline R Squared / Log likelihood & 0.16 & & $-67553.96^{\#}$ & \\
\hline
\end{tabular}

Notes: ${ }^{* *}$ significant at 1 percent, * significant at 5 percent, + significant at 10 percent MLE method estimates CF participation and fuelwood consumption simultaneously.

\# log likelihood ratio of joint estimation. The coefficients of household CF participation are in table 4.

Wald test of independent equations. $($ rho $=0)$ : chi2 $(1)=7.65$ Prob $>$ chi2 $=0.0057$ 
Table 6. Average differences in fuelwood consumption for participating households and CF villages.

Firewood Consumption

Households CF Villages

A. Mean Difference comparison

Fuelwood consumption

$259^{* *}$

$202 *$

For participant only:

Asset non-poor

80

Do not read newspaper

829 **

Other Castes

179 *

B. MLE based estimates

Fuelwood consumption

$744^{* *}$

$-90$

C. Propensity score based estimates

Nearest Neighbor, equal weights

172

$-32$

Radius Matching

290 **

$-10$

Kernel Matching

109

$-13$

Notes: ${ }^{* *}$ significant at 1 percent, ${ }^{*}$ significant at 5 percent.

Asset poor households are defined as those in the bottom two quintiles of the asset index constructed from possessed land and other assets. 


\begin{tabular}{|c|c|c|c|c|}
\hline \multirow[b]{2}{*}{ Variables } & \multicolumn{2}{|c|}{ Non-CF } & \multicolumn{2}{|c|}{ CF } \\
\hline & Mean & $\begin{array}{l}\text { Standard } \\
\text { Deviation }\end{array}$ & Mean & $\begin{array}{l}\text { Standaro } \\
\text { Deviation }\end{array}$ \\
\hline Average Firewood Consumption & 753 & 642.12 & $955^{*}$ & 642.57 \\
\hline Andhra Pradesh & 0.18 & 0.38 & 0.10 & 0.30 \\
\hline Madhya Pradesh & 0.19 & 0.39 & 0.28 & 0.45 \\
\hline Orissa & 0.26 & 0.44 & $0.40^{*}$ & 0.50 \\
\hline Uttar Pradesh & 0.32 & 0.47 & 0.13 & 0.33 \\
\hline West Bengal & 0.05 & 0.22 & 0.10 & 0.30 \\
\hline Forest Dummy & 0.39 & 0.49 & $0.88^{* *}$ & 0.33 \\
\hline Forest Outside Village Within Reach Dummy & 0.47 & 0.50 & $0.83^{* *}$ & 0.38 \\
\hline All Weather Road Dummy & 0.64 & 0.48 & 0.63 & 0.49 \\
\hline Post Office Dummy & 0.41 & 0.49 & 0.30 & 0.46 \\
\hline Middle School Education Dummy & 0.73 & 0.45 & 0.83 & 0.38 \\
\hline Self Help Group Dummy & 0.15 & 0.36 & 0.15 & 0.36 \\
\hline Proportion ST & 0.17 & 0.30 & $0.37^{* *}$ & 0.33 \\
\hline Proportion SC & 0.24 & 0.23 & $0.17^{*}$ & 0.20 \\
\hline Proportion OBC & 0.30 & 0.28 & 0.25 & 0.24 \\
\hline Majority Firewood Dependent Dummy & 0.33 & 0.47 & $0.85^{* *}$ & 0.36 \\
\hline
\end{tabular}

Note: Differences are ${ }^{* *}$ significant at 1 percent, and ${ }^{*}$ significant at 5 percent. 


\section{Table A.2. Characteristics of CF and Non-CF households.}

\section{Non CF}

Households

CF Households

\begin{tabular}{|c|c|c|c|c|}
\hline Variables & Mean & $\begin{array}{l}\text { Standard } \\
\text { Deviation }\end{array}$ & Mean & $\begin{array}{l}\text { Standard } \\
\text { Deviation }\end{array}$ \\
\hline Annual Fuelwood Consumption (Kg) & 745.88 & 880.87 & $1005.15^{* *}$ & 595.64 \\
\hline Andhra Pradesh & 0.18 & 0.38 & 0.07 & 0.26 \\
\hline Madhya Pradesh & 0.19 & 0.39 & 0.26 & 0.44 \\
\hline Orissa & 0.26 & 0.44 & 0.46 & 0.50 \\
\hline Uttar Pradesh & 0.32 & 0.47 & 0.09 & 0.29 \\
\hline West Bengal & 0.06 & 0.23 & 0.11 & 0.32 \\
\hline Fuelwood used for consumption \& enterprise & 0.04 & 0.20 & 0.07 & 0.26 \\
\hline Self Employed in Non-Agriculture & 0.10 & 0.31 & 0.07 & 0.26 \\
\hline Agricultural Labor & 0.37 & 0.48 & 0.54 ** & 0.50 \\
\hline Non-Agricultural Labor & 0.06 & 0.24 & $0.01^{* *}$ & 0.08 \\
\hline Other Non Agricultural Occupation & 0.10 & 0.30 & $0.05^{* *}$ & 0.22 \\
\hline Scheduled Tribe & 0.18 & 0.38 & $0.38^{* *}$ & 0.49 \\
\hline Scheduled Caste & 0.24 & 0.43 & $0.07^{* *}$ & 0.26 \\
\hline Other Backward Class & 0.30 & 0.46 & 0.39 * & 0.49 \\
\hline Land Possessed (ha) & 0.82 & 1.66 & 0.81 & 1.27 \\
\hline Own Phone, Radio, TV Dummy & 0.29 & 0.45 & $0.22 *$ & 0.41 \\
\hline Read Newspaper Dummy & 0.13 & 0.33 & 0.11 & 0.31 \\
\hline Female Headed Households & 0.07 & 0.26 & $0.03^{* *}$ & 0.18 \\
\hline Average Age of Household Members & 26.77 & 11.37 & $24.35^{* *}$ & 8.32 \\
\hline Household Size & 5.03 & 2.54 & 5.54 ** & 2.66 \\
\hline Fuelwood Price (Rs/Kg) & 0.75 & 0.32 & 0.74 & 0.34 \\
\hline Total Govt Forest Area (ha) & 70.44 & 254.23 & 64.12 & 114.67 \\
\hline Total Village Common Land (ha) & 75.97 & 208.98 & $14.38 * *$ & 20.03 \\
\hline All Weather Road Dummy & 0.65 & 0.48 & 0.59 & 0.49 \\
\hline CF Village & 0.06 & 0.24 & $0.83^{* *}$ & 0.37 \\
\hline Proportion of CF households in Village & 0.01 & 0.05 & $0.68^{* *}$ & 0.33 \\
\hline
\end{tabular}

Note: Differences are ${ }^{* *}$ significant at 1 percent, and ${ }^{*}$ significant at 5 percent.

Total number of households are 8307 of which 151 are CF households. 


\begin{tabular}{|c|c|c|}
\hline Dependent variable: CF Village & Coefficient & $\begin{array}{c}\text { Standard } \\
\text { Errors }\end{array}$ \\
\hline Constant & $-3.07^{* *}$ & 0.50 \\
\hline Andhra Pradesh & -0.08 & 0.35 \\
\hline Madhya Pradesh & 0.12 & 0.26 \\
\hline Uttar Pradesh & 0.06 & 0.32 \\
\hline West Bengal & $0.65+$ & 0.39 \\
\hline Forest Dummy & $0.87^{* *}$ & 0.24 \\
\hline Forest Outside Village Within Reach Dummy & 0.09 & 0.27 \\
\hline All Weather Road Dummy & 0.09 & 0.22 \\
\hline Post Office Dummy & -0.16 & 0.23 \\
\hline Middle School Education Dummy & $0.58 *$ & 0.24 \\
\hline Self Help Group Dummy & 0.17 & 0.30 \\
\hline Heterogeneity Index & 0.30 & 0.53 \\
\hline Majority Fuelwood Dependent Dummy & 0.94 ** & 0.27 \\
\hline Gini Coefficient for land possessed in village & -0.46 & 0.62 \\
\hline 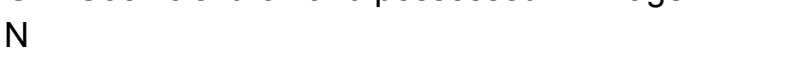 & 524 & \\
\hline Log likelihood & -107.55 & \\
\hline Pseudo R squared & 0.24 & \\
\hline
\end{tabular}

Notes: ${ }^{* *}$ significant at 1 percent, ${ }^{*}$ significant at 5 percent, + significant at 10 percent 